\title{
What Has Changed in the Diagnosis and Treatment of Colorectal Cancer?
}

\section{Geçmişe Göre Günümüzde, Kolorektal Kanseri Tanısı, Önlenmesi ve Tedavisinde Ne Değişti?}

\author{
(D) Fatin Rüştü POLAT ${ }^{1}$, (1) Yasin DURAN ${ }^{1}$, (1) ihsan GÜNDÜZ² \\ ${ }^{1}$ Tekirdağ Namık Kemal University Faculty of Medicine, Department of General Surgery, Tekirdağ, Turkey \\ 2Tekirdağ State Hospital, Clinic of Surgical Gastroenterology, Tekirdağ, Turkey
}

\begin{abstract}
Colorectal cancer (CRC); is the most common malignancy in the gastrointestinal tract. CRC is associated with significant morbidity and mortality in the worldwide. CRC is the third most common cancer-related death in both men and women globally. The overall 5-year survival rate is $50 \%$ last decade (1975). Currently this rate is over 75-80\%. In this case; early diagnosis, prevention and effective treatment methods were the main factors. Nowadays, Genetic Analysis test, Fecal Occult Blood testing and colonoscopy methods are used in screening. Genetic Analysis testing is the best method for the lead time. In addition, polypectomy was performed in precarious patients and was classified as preventable disease.
\end{abstract}

Keywords: Colorectum, cancer, early diagnosis, lead time, prevention of cancer

\section{ÖZ}

Kolorektal kanser (KRK), dünya çapında önemli morbidite ve mortalitesi olan bir hastalıktır. KRK, dünya genelinde hem erkeklerde hem de kadınlarda kansere bağlı üçüncü en yaygın ölüm nedenidir. Geçmiş yıllarda (1975) beş yıllık hayatta kalma \%50 iken günümüzde bu oran \%75-80'dir. Bu duruma; erken evrede tanı, prevansiyon ve etkili tedavi yöntemleri temel etken olmuştur. Günümüzde taramada Genetik Analiz testi, Gaita Gizli Kan testi ve kolonoskopi yöntemleri kullanılmaktadır. Lead time en iyi yöntem Genetik Analiz testidir. Ayrıca günümüzde riskli olgulara polipektomi yapılarak önlenebilir bir hastalık kategorisine alınmıştır.

Anahtar Kelimeler: Kolorektum, kanser, erken tanı, lead time, kanserde korunma

\section{INTRODUCTION}

Cancer is a non-lethal genetic disorder in the cell, more simply defined as uncontrolled cell proliferation. The activation of oncogenes, inactivation of tumor suppressor genes, impairment of DNA repair ability, inability to perform apoptosis, reprogramming the cell energy metabolism that has been recently studied, and the protection of the tumor cell from the immune system constitute the basic physiopathology ${ }^{1-3}$. One or more physiopathological conditions is caused by hereditary, physical, chemical and/or biological (bacteria, virus) factors ${ }^{1,2}$.

Colon is the approximately $150 \mathrm{~cm}$ part of the gastrointestinal system between the ileocecal valve and the rectosigmoid corner ${ }^{3,4}$. It consists of the cecum, ascending colon, transverse colon, descending colon, and sigmoid colon ${ }^{3,4}$. The rectum is considered as a separate organ today. The nutrition of the colon is provided by the branches originating from the two main arteries of the aorta. The upper mesenteric artery is the midgut artery, it supplies the right half of the colon (a. ileocolic, right colic and middle colic artery). The lower mesenteric artery is the artery of the hindgut, it supplies the left half of the colon (left colic artery, sigmoid artery). These two networks are connected to each other by the arc of riolan. The venous anatomy of the colon is generally similar to the anatomy of the artery. The right colon drains into the portal system through the vena mesenterica superior, the left colon

Address for Correspondence: Fatin Rüştü POLAT MD, Tekirdağ Namık Kemal University Faculty of Medicine, Department of General Surgery, Tekirdağ, Turkey E-mail: frpolat@nku.edu.tr ORCID ID: orcid.org/0000-0001-6628-2109

Received: 20.12 .2019 Accepted: 07.12.2020

๑Copyright 2021 by the Tekirdağ Namık Kemal University Faculty of Medicine / Namık Kemal Medical Journal published by Galenos Publishing House. 
through the vena mesenterica inferior. Likewise, the drainage of the lymphatic system takes place along the arteries and occurs in four main stages; epicolic, intermediate, paracolic and prespinal (paraaortic) lymph node ${ }^{3}$.

\section{Its Epidemiology and Distribution}

It is the most common malignancy in the gastrointestinal tract $^{4}$. In terms of mortality, it is among the third most common causes of death after lung and prostate cancer. It shows geographic differences throughout the world and its incidence in undeveloped regions is 6.5/7.7 per 100,000 women/men and around 50.9/60.8 in developed regions ${ }^{5}$. The distribution of colon tumors is often seen in the sigmoid colon and then in the cecum ${ }^{6,7}$.

\section{Etiology}

Its etiology is not known for certain, but genetic and environmental factors that affect the colon mucosa play a role ${ }^{6}$. In terms of genetic factors, colon cancer is more common in those with familial polyposis or familial adenoma $(>90 \%)$. It is also known that colon cancer develops without the presence of polyposis [hereditary non-polyposis colorectal cancer (CRC) or Lynch syndrome 1, 2] ${ }^{8}$. It has been suggested that one or more of the adenomatous polyposis coli (APC), $p 53$, delaeted in colorectal cancer (DCC), MCC and $K$-ras genes play a role ${ }^{5,8}$. When examined in terms of diet, it is known that excessive amounts of meat and fat ingested change the colon flora and establish a ground for cancer $^{3-8}$. Studies suggesting an increased incidence of colon cancer after cholecystectomy or ureterosigmoidostomy have been conducted, but their accuracy has not been proven 9 . It is known that there is a relationship between inflammatory bowel diseases and colon cancer $^{10}$. In addition, age is an important risk factor for colon cancers $^{11}$. It increases significantly after the age of 50 years ${ }^{11}$. Correct determination of risk factors is important for effective results of community monitoring and screening programs.

Genetics in CRC screening: Somatic mutation in adenoma plays a role in the majority of colon cancers and hereditary (germline) mutation in some colon cancers. When mutations occur in more than one gene, it results in cancer. It takes a long time, such as 10-15 years, for a mutation in a normal cell to result in cancer (Sojourn time). Therefore, lead time can be kept much shorter with screening programs. $\mathrm{K}-, \mathrm{N}-, \mathrm{H}$-ras (especially $K$-ras) activation of proto-oncogenes, APC which are tumor suppressor genes, DCC and $p 53$ mutation, mutation of mismatch repair (MMR) genes, especially the $h M S H 2$ gene among the MMRs play a major role in the cancerization of colon cells (50\%). In addition, hMSH3, 6 and hPMS2 and 3, of the $M M R$ genes, also play a role. Multiple gene mutations are detected by DNA analysis.
Fecal Occult Blood test (FOBT) in CRC screening: With the formation of cancer tissue or adenomas reaching a certain size, bleeding occurs into the lumen. In this case, the diagnosis of cancer becomes meaningful after a certain period of time to occur cancer2,3.

Colonoscopy in CRC screening: In $20 \%$ of cases, it may give false negative results due to insufficient bowel cleansing or inability to visualize the mass.

Lead time in early diagnosis: Genetic analysis test > FOBT > colonoscopy.

Pathogenesis: The majority of these tumors originate from the glandular epithelium and are adenocarcinoma ${ }^{8}$. It originates in the mucosal epithelium and spreads in the lumen and/or intramural region ${ }^{8}$.

Classification in CRC: Two types of cancer are macroscopically seen in the colon ${ }^{6}$. a) "Cauliflower" is often seen on the right side of the colon, b) "ring-structure" is seen on the left side of the colon.

\section{Clinical Symptoms and Signs}

It is an inapparent disease and gives late symptoms. Initially, it starts with anemia and lower gastrointestinal system bleeding, then progresses as a change in bowel habit (diarrhea, constipation, change in stool characteristics). Non-specific symptoms such as abdominal pain, nausea, tenesmus, and weight loss are observed. Obstruction signs are observed in patients with more advanced stage. In other words, the clinical picture varies depending on the location, macroscopic structure, stage and complications of the tumor ${ }^{3}$. Tumors located on the right side of the colon present with anemia, and those located on the left side with signs of obstruction. In developed countries, while $87.9 \%$ of the cases were admitted to the emergency service with obstruction in the 1925s (stage 4$)^{6}$, today there has been a decrease in admission to the emergency services with obstruction (76-80\%). This has been achieved with the effective use of diagnostic methods and conscious society ${ }^{7}$. However, a significant decrease is not observed in undeveloped societies.

\section{Screening and Diagnosis}

Cancer screenings are for detecting diseases at an early stage, thus reducing the incidence of advanced stage patients and reducing mortality ${ }^{11}$. The delay in diagnosis of colon cancer is still an important problem in today's underdeveloped societies. The biggest factor in this situation is the education and social status of the patients. Tests for colon cancer screening include FOBT, genetic analysis test and structural examination [colonoscopy, capsule endoscopy, double contrast barium graphy, computed tomographic (CT) colonography or 
virtual colonoscopy] tests. The screening program should be performed at the age of 50 years in normal individuals, and around the age of 40 years in individuals at risk (family history or inflammatory bowel disease).

\section{Prevention and Treatment}

Cancer prevention is considered as primary and secondary ${ }^{11}$. Primary prevention is based on the elimination of biological, genetic and environmental factors, and secondary prevention is based on the early diagnosis and treatment of premalignant lesions. Chemoprevention; there are studies showing that regular aspirin or non-steroidal anti-inflammatory drugs use reduces colon cancers by $30-50 \%{ }^{12}$.

The main treatment method in patients diagnosed with cancer is surgery. First of all, it is evaluated whether the tumor is local, regional or systemic (positron emission tomography-CT, CT).

For patients with local tumors: With conventional, laparoscopic or robotic methods, the resection of the primary tumor with lymphatics that it drains $\left(R_{0^{\prime}}\right.$ radical resection) and anastomosis for intestinal continuity are applied. Today, endoscopic muco-submucosal resection method is used in developed countries for early stage tumors.

For cases with regional tumors: If the tumor has invaded neighboring organs, the tumor mass is resected en-bloc after neoadjuvant chemoradiotherapy.

For patients with systemic disease: If the tumor cannot be removed surgically, a proximal diverting ostomy is performed and palliative treatment is applied ${ }^{1-3,11}$. If metastasis is present, in these cases, metastasis often occurs in the liver (70-80\%) ${ }^{1}$. Partial hepatectomy, metastasectomy, radiofrequency ablation, embolization, transarterial chemoembolization, transarterial radioembolization, and chemotherapy are applied.

Prognosis: In developed countries, while the five-year survival rate was $50 \%$ in the past years (1975), this rate is $75-80 \%$ today ${ }^{13}$. In developing countries, patients are still diagnosed at a late stage, which decreases the patient's five-year survival rate $^{12,13}$.

\section{CONCLUSION}

CRC is the third most common cause of death from cancer worldwide ${ }^{14}$. Although colon cancer is more common in developed countries compared to underdeveloped countries ${ }^{15,16}$, today, it can be prevented by screening programs in developed countries. While cure can be achieved with early diagnosis and effective surgery, unfortunately it is still an important health problem in undeveloped countries. In undeveloped countries, the disease can be brought to a preventable level with the education of individuals and effective implementation of screening programs.

\section{Ethics}

Peer-reviewed: Externally peer-reviewed.

\section{Authorship Contributions}

Surgical and Medical Practices: F.R.P., Concept: F.R.P., Design: F.R.P., Data Collection or Processing: F.R.P., Analysis or Interpretation: F.R.P., Y.D., I.G., Literature Search: F.R.P., Y.D., i.G., Writing: F.R.P.

Conflict of Interest: No conflict of interest was declared by the authors.

Financial Disclosure: The authors declared that this study received no financial support.

\section{References}

1. Kitagawa $Y$, Daniel T. Dempsey. Stomach In: Schwartz SI, ed. Principles of Surgery. Seventh ed. New York: McGraw-Hill International Inc. 2015;103598.

2. Dharmarajan S, Halpin VJ, Hawkins WG Stomach, Klingensmith ME (Editor). The Washington Manual of Surgery. Washington. The, 5th Edition. Lippincott Williams \& Wilkins. 2008; p. 168-180.

3. Buğra D. Genel Konular: Kemal Alemdaroğlu, ed. Kolon Rektum ve Anal Bölge Hastalıkları. 1 Baskı. İstanbul: Ajans Plaza Tanıtım ve İletişim Hizmetleri Ltd. şti. 2003:1-119.

4. Ulualp K. Kolon Tümörleri. Andican A.A. ed. Abdominal Operasyonlar. 1. Baskı. İstanbul: Nobel Kitabevi. 2008: p. 625-60.

5. Parkin DM, Bray F, Ferlay J, Pisani P. Global cancer statistics, 2002. CA Cancer J Clin. 2005;55:74-108.

6. Burgess HA. A Lecture on cancer of the gastro-intestinal tract. Br Med J. $1927 ; 1: 1-5$.

7. Winawer SJ, Zauber AG, Ho MN, O'Brien MJ, Gottlieb LS, Sternberg SS, et al. Prevention of colorectal cancer by colonoscopic polypectomy. The National Polyp Study Workgroup. N Engl J Med. 1993;329:1977-81.

8. Sayek I. Kolon Rectum Kanserleri. Sayek I. Ed. Temel Cerrahi. 3. Baskı. Ankara: Güneş Kitabevi. 2004. p. 1243-55.

9. Halldorsson MO, Hauptmann $M$, Snaebjornsson $P$, Haraldsdóttir $K H_{\text {, }}$ Aspelund T, Gudmundsson EF, et al. The risk of developing a mismatch repair deficient colorectal cancer after undergoing cholecystectomy. Scand J Gastroenterol. 2018;53:972-5.

10. Taylor CC, Millien VO, Hou JK, Massarweh NN. Association Between Inflammatory Bowel Disease and Colorectal Cancer Stage of Disease and Survival. J Surg Res. 2020;247:77-8.

11. Ertürk S. Kolorektal kanserde epidemiyoloji, etiyolojide rol oynayan etkenler tarama ve kemoprevansiyon. Baykan A. Ed. Kolon ve Rekum kanserleri. 1. Baskı. İstanbul: Seçil ofset Matbaacılık Ltd. Şti. 2010. p. 15-30.

12. Jänne PA, Mayer RJ. Chemoprevention of colorectal cancer. N Engl J Med. 2000;342:1960-8.

13. Siegel R, Naishadham D, Jemal A. Cancer statistics, 2013. CA Cancer J Clin. 2013;63:11-30.

14. Wu R, Wang L, Yin R, Hudlikar R, Li S, Kuo HD, et al. Epigenetics/epigenomics and prevention by curcumin of early stages of inflammatory-driven colon cancer. Mol Carcinog. 2020;59:227-36.

15. Saifutdinova KR, Sushkov OI, Achkasov SI. Profilaktika kartsinomatoza pri rake obodochnoĭ kishki [Prevention of carcinomatosis in colon cancer]. Khirurgiia (Mosk). 2019;88-92.

16. Polat FR. Rectosigmoidoscopy: Retrospective Evaluation of 295 Cases. Kafkas J Med Sci. 2011;1:21-4. 